\title{
Otizmli Bir Bireyin Azaltılması ve Artırılması İstenen Davranışlarında İşlevsel İletişim Öğretiminin Etkililiği*
}

\section{Yusuf ALPDOĞAN** ve Elif SAZAK***}

Öz: Bu araştırmada, Otizm Spektrum Bozukluğu (OSB) olan bir bireyin problem davranışlarının ortadan kaldııılmasında ve dersle ilgilenme davranışlarının artırılmasında işlevsel iletişim öğretimin etkililiği incelenmiştir. Araştırma, 11 yaşında, OSB tanısı almış bir erkek çocuğuyla yürütülmüştür. Araştırmada, nicel araştırma türlerinden deneysel yöntem kullanılmıştır. Araştırma, deneysel yöntem türlerinden denek sayısına göre planlanmış ve araştırmada tek denekli araştırma modellerinden yoklama evreli ortamlar arası çoklu yoklama modeli kullanılmıştır. Araştırma sonucunda, örneklemin problem davranışları nesne elde etmek ve zor bir görevden kaçmak amacıyla sergilediği, işlevsel iletişim öğretimi ile iletişim becerileri öğretildiğinde problem davranışların ortadan kalktığı ve ikinci bağımlı değişken olan örneklemin etkinlikle ilgilenme davranışlarının ise arttığı görülmüştür. Araştırma sonuçlarından hareketle ileri araştırmalara yönelik önerilerde bulunulmuştur.

Anahtar Sözcükler: Otizmli Birey, İşlevsel İletişim Öğretimi, Problem Davranışlar, Artırılması İstenen Davranışlar

\section{Effectiveness of Functional Communication Teaching in Reducing Inappropriate Behaviors of a Child with Autism}

\begin{abstract}
In this study, the effectiveness of functional communication teaching in eliminating the problem behaviors of an individual with Autism Spectrum Disorder (ASD)

\footnotetext{
*Bu araştırma Prof. Dr. Elif Sazak danışmanlığında, Yusuf Alpdoğan tarafindan hazırlanan yüksek lisans tezinden üretilmiştir.

**Sorumlu Yazar / Correspondence: Van Yüzüncü Y1l Üniversitesi, Türkiye, e-mail: yusufalpdogan1465@gmail.com, ORCID: 0000-0002-6615-397X

***Prof. Dr. Abant İzzet Baysal Üniversitesi, Eğitim Fakültesi, elifsazak@hotmail.com, ORCID: https://orcid.org/0000-0003-3530-9588
} 
and increasing the lesson engagement behaviors was examined. The study was conducted with an 11-year-old boy diagnosed with ASD. Experimental method, one of the quantitative research types, was used in the research. The research was planned according to the number of subjects, which is one of the experimental method types, and the multiple probe model between the environments with probe phase, one of the single-subject research models, was used. As a result of the research, it was seen that the sample exhibited problem behaviors in order to obtain an object and escape from a difficult task. When the communication skills were taught with functional communication teaching, the problem behaviors disappeared and the second dependent variable, the participant's behavior of dealing with the activity, increased. Based on the results of the research, suggestions for further research were made

Keywords: İndividual with autism, Functional communication teaching, problem behaviors, behaviors desired to increase

\section{Giriş}

Tarih boyunca insanlar bir arada yaşamış, ihtiyaçlarını temin etmek amacıyla çevresindeki bireylerle çeşitli şekillerde etkileşim ve iletişim kurmuşlardır. Sosyal etkileşim ve iletişim olarak adlandırılan bu durum yalnızca konuşma ile açıklanmamaktadır (Mengi, 2019). İnsanların bilgi ve duygu aktarımını sağlamak amacıyla kullandıkları her şey sosyal etkileşim ve sosyal iletişim aracıdır (Winborn, Wacker, Richman, Asmus ve Geier, 2002). Bu araçlar tarih boyunca değişim ve gelişim göstermiştir (Richman, Wacker ve Winborn, 2001). Ancak sosyal etkileşim, iletişim ve bunları sağlayan araçlarının çeşitli şekillere ulaşmasına ve artmasına rağmen diğer taraftan bireylerin yalnızlaşması çok tartışı1ır olmuştur (Çopuroğlu ve Mengi, 2014). İletişim problemleri olarak adlandırılan bu durum (Richman ve diğerleri 2001), farklı zamanlarda bireyleri olumsuz yönde etkilemektedir. $\mathrm{Bu}$ problemler diğer taraftan doğuştan getirilen farklılıklara ve gelişim özelliklerine bağlı olarak yetersizliği olan bireyleri ve bu yetersizlikler içerisinde de özellikle OSB olan bireylerin başta sosyal etkileşim ve iletişimleri olmak üzere, günlük yaşam aktivitelerini önemli derece etkilemektedir (Aydın, 2008; Carr ve Durand, 1985, Mengi, 2019). 
DSM -5’te OSB'nin en belirgin özelliği olan sosyal etkileşim ve iletişimdeki yetersizlik; alıcı dil, ifade edici dil, jest ve mimik kullanma gibi sözel olmayan iletişim sorunları olarak açıklanmıştır (DSM-5, 2014). OSB olan bireylerde, sosyal etkileşim ve iletişimde görülen yetersizliklere bağlı olarak problem davranış sorunları da ortaya çıkmaktadır (Winborn ve diğerleri, 2002). Normal gelişim gösteren bireylerde dil becerileri edinildikten sonra, dili kullanmada ve iletişimde yaşanılan sorunların ortadan kalktığı ifade edilmektedir (Carr, Levin, McConnachie, Carlson, Kemp ve Smith, 1994). Normal gelişim gösteren bireyler bir yaş civarında amaçsız iletişimden amaçlı iletişime doğru bir geçiş yaparlar ve ilk sözcükleri kullanmaya başlarlar (Koegel ve Koegel, 2006; akt. Yücesoy Özkan, 2014). İletişim becerilerini kazanmada farklılıklar ve yetersizlikler gösteren bireyler ise, sosyal iletişim kurmak yerine bazı uygun olmayan davranışlarda bulunurlar. (Çopuroğlu ve Mengi, 2014). Bu davranışlar arasında vurma, ısırma ve bağırma sayılabilir. (Carr, Levin, McConnachie, Carlson, Kemp ve Smith, 1994; McLean ve McLean, 1993; Reichle ve Johnston, 1993; akt. Erbaş, 2001).

Problem davranışlar, sosyal kabulü olmayan davranışlar olarak açıklanmaktadır (Durand, 1999). Alanyazında, problem davranışların bazı işlevleri olduğu belirtilmektedir (Carr ve Durand, 1985). Bu işlevler genel olarak ilgi elde etme, nesne elde etme, duyusal uyaran elde etme ve bir görevden kaçma/kaçınma davranışlarıdır (Erbaş, 2005). OSB olan bireylerin problem davranışlarının ortadan kaldırılması birey, toplum ve uygulamacılar için umut etmenin ötesinde, bu bireylerin iletişim becerilerinin desteklenmesi ve arttırılması gerekmektedir (Sucuoğlu, 2009; Sönmez ve Vuran, 2008). Problem davranışların ortadan kaldırılmasında kullanılan iletişim becerilerin önemi sadece problem davranışların ortadan kaldırılmasıyla açıklanmaz, bununla beraber bireylerin sosyal kabullerini de arttırdığı söylenebilir (Mengi ve Alpdoğan, 2020). Problem davranışların ortadan kaldırılmasında problem davranışa alternatif seçilecek olan iletişim becerilerin toplum tarafından kabul edilebilirliğinin göz önünde bulundurulması, bu davranışın kalıcılığı ve genellemesi için oldukça önemlidir (Demir, 2017).

OSB olan bireylerin problem davranışlarını ortadan kaldırmak ve iletişim becerileri kazandırmak amacıyla alan yazında çeşitli uygulamalar bulunmaktadır (Detrich, 2012; National Autism Center, NAC, 2010; Tekin-İftar ve Olçay-Gül, 2012). Bu uygulamalar genel olarak alternatif ve destekleyici iletişim, akran destekli müdahaleler, ayrımlı pekiştirme, davranışsal ivme, görsel destekler, egzersiz ve hareket, ipucu sunma, 
işlevsel davranışsal değerlendirme, kendini yönetme, model olma, öncüle dayalı uygulamalar, pekiştirme ve tepkiyi durdurma/yeniden yönlendirme şeklinde sıralanabilir (National Clearinghouse on Autism Evidence and Practice, NCAEP, 2020). Ayrica işlevsel iletişim öğretimi de (functional communication training), etkileşim ve iletişim yetersizliği nedeniyle problem davranışlar sergileyen OSB’li bireylerin eğitiminde kullanılması etkili görülen bir uygulamadır. İşlevsel iletişim öğretimi öncüllere odaklanarak problem davranışları ortadan kaldırmayı ve iletişim davranışlarını destekleyip artırmayı amaçlar (Carr ve Durand, 1985; Ingersoll ve Dvortcsak, 2006). Problem davranış ortaya çıkmadan önceki bireylerin yaşantıları, problem davranışın ortaya çıkması üzerinde oldukça etkilidir (Durand, 1999; Kurt, 2012). İşlevsel iletişim öğretiminin etkililiği üzerinde, problem davranışın öncülleri tespit edildikten sonra araştırmacının alternatif iletişim becerilerini doğru seçmesi oldukça önemlidir (Sucuoğlu, 2012).

Problem davranışların ortadan kaldırılmasında işlevsel iletişim öğretiminin etkili olduğunu ortaya koyan çok sayıda araştırma (Boyle, Ortman, Beckman, Aholt, ve Keenan, 2018; Brown ve diğerleri 2000; Carr ve Durand, 1985; Davis ve diğerleri 2009; Derby ve diğerleri 1997; Durand, 1999; Durand ve Carr,1991; Fisher ve diğerleri 2004; Gerow, Radhakrishnan, Davis, Hodges ve Feind, 2020; Ghaemmaghami, Hanley ve Jessel, 2021; Hagopian, Wilson, ve Wilder, 2001; Harding ve diğerleri 2009; Mildon, Moore ve Dixon, 2004; Kim ve Utley, 2007; Kuhn, Chirighin ve Zelenka, 2010; Peck-Peterson ve diğerleri 2005; O’Brien, ve diğerleri, 2021; O’Neill ve Sweetland-Baker, 2001; Richman, Wacker, ve Winborn, 2001; Suess, Schieltz, Wacker, Detrick ve Podlesnik, 2020; Volkert, Winborn ve diğerleri 2002; Worsdell ve diğerleri 2000) olmasına rağmen Türkiye'de Erbaş (2002) tarafından gerçekleştirilen doktora tez çalışması ve Alpdoğan (2018) tarafından gerçekleştirilen yüksek lisans tez çalışması dışında işlevsel iletişim öğretimin yapıldığı başka bir çalışmaya rastlanmamış olması, Türkiye'de bu teknik üzerinde çalışılması gerektiğini düşündürmüştür. Dolayısıyla, yukarıda belirtilen bu yararlar dikkate alındığında, OSB'li bireylerin problem davranışların ortadan kaldırılmasında ve bu bireylerin etkinlikle ilgilenme sürelerinin artırılmasında işlevsel iletişim öğretiminin kullanıldığı uygulamaların etkililiğini ve verimliliğini belirlemeye yönelik araştırmalara gereksinim olduğu görülmektedir. $\mathrm{Bu}$ araştırma, OSB’li bireylerin problem davranışlarının ortadan kaldırılmasında ve etkinlikle ilgilenme davranışlarının 
arttırılmasında işlevsel iletişim öğretimin kullanıldığı uygulamaların etkililiğini belirleme amacını taşımaktadır. Bu amaç doğrultusunda şu sorulara yanıt aranmıştır.

1- OSB'li bir bireyin problem davranışlarının ortadan kaldırılmasında ve artırılması hedeflenen davranışları üzerinde işlevsel iletişim öğretimi etkili midir?

2- İşlevsel iletişim öğretimi sosyal olarak geçerli bir uygulama mıdır?

3- İşlevsel iletişim öğretimi, öğretilen hedef davranışların sürdürülmesi üzerinde etkili midir?

\section{Yöntem}

\section{Araştırma Modeli}

$\mathrm{Bu}$ araştırmada, OSB olan bir bireyin problem davranışlarının ortadan kaldırılmasında ve etkinlikle ilgilenme davranışlarının arttırılmasında işlevsel iletişim öğretimin etkililiğini incelemek amacıyla nicel araştırma türlerinden deneysel yöntem kullanılmıştır. Deneysel yöntem, araştırmanın sorularını cevaplamak veya hipotezi test etmek amacıyla araştırmacı tarafından geliştirilen plandır (Creswell, 2017). Deneysel yöntemler ikiye ayrılır: a) denek sayısı, b) bağımsız değişken sayısı. Bu araştırma, deneysel yöntem türlerinden denek sayısına göre planlanmış ve araştırmada tek denekli araştırma modellerinden yoklama evreli ortamlar arası çoklu yoklama modeli kullanılmıştır. Ortamlar arası çoklu yoklama modeli bir bağımsız değişkenin etkililiğinin üç farklı ortamda araştırıldı̆̆ı modeldir (Tekin-İftar, 2012 ). Ayrıca araştırma verileri nitel araştırma türlerinden betimsel analiz ile de desteklenmiştir.

\section{Bağımsız Değişken}

Araştırmanın bağımsız değişkeni; işlevsel iletişim öğretimidir. Araştırmada işlevsel iletişim öğretimi, OSB olan bir bireyin problem davranışlarının ortadan kaldırılmasında ve etkinlikle ilgilenme davranışlarının arttırılmasında etkililiğini ortaya koymak amacıyla uygulanmıştır.

\section{Bağımlı Değişken}

Araştırmanın bağımlı değişkeni araştırma örneklemin sergilediği problem davranışlar (eşyaları firlatma, vurma ve ısırma) ve etkinlikle ilgilenme davranışlarıdır. 


\section{Bağımlı değişkenlerin belirlenmesi.}

Araştırmada, bağımlı değişkenlerin belirlenmesi için örneklemin davranışları doğrudan gözlemlenmiş, örneklemi iyi tanıyan kişilerle görüşmeler yapılarak veriler toplanmıştır. Bağımlı değişkenlerin belirlenmesinde ilk olarak doğrudan gözlem kayıt tekniği olan Öncül-Davranış-Sonuç (ÖDS) tekniğini için araştırmacı, örneklemin davranışlarını 5 gün üst üste sınıf ortamında, okul bahçesinde, spor salonunda ve evde olmak üzere videoya kaydetmiş, ÖDS formuna aktarmıştır. Araştırmacı dolaylı kayıt teknikleri için, Anne Görüşme Formu ve İşlevsel Değerlendirme Tarama Aracını kullanmıştır. İşlevsel Değerlendirme Tarama Aracı, Erbaş, Kırcaali-İftar ve Tekin-İftar (2004) tarafından geliştirilmiştir (Sucuoğlu, 2012). İşlevsel Değerlendirme Tarama Aracı, örneklemin annesi ve babası ile görüşme yapılarak doldurulmuş ve tarama sonucunda örneklemin problem davranışlarının "eşyaları firlatma", "vurma" ve "1sırma" olduğu görülmüştür. Araştırmada, örneklemeye yönelik bağımlı değişken seçilirken, bu değişkenlerin örneklem için işlevsel ve öncelikli öğretilmesi ya da azaltılması gereken değişkenler olmasına özen gösterilmiştir.

\section{Ortam ve Araç Gereçler}

Bu araştırma Bolu İli merkezinde, örneklemin yaşadığı evin salonunda, örneklemin eğitim gördügü okuldaki sınıfinda ve okuldaki spor salonunda yürütülmüştür. Araştırma esnasında ortamlarda "mola kartı", işlevsel etkinliklerin içerinde yer aldığı dört kutu ve video kaydı yapmak için kamera bulundurulmuştur. Ortamlarda uygulamaların iyi bir şekilde kaydedilmesi için kamera araştırmacı ve örneklemi görecek şekilde çalışma masanın karşı duvarına yerleştirilmiştir. Oturumlarda sadece araştırmacı ve örneklem bulunmuştur. Araştırmanın uygulama esnasında örneklemin etkinlikleri yarıda kesmesini engellemek amacıyla çıkış tarafına araştırmacının sandalyesi yerleştirilmiştir.

Araştırmada, işlevsel iletişim öğretimi amacıyla hazırlanan araç gereçler, iletişim kartlarından ve pekiştireçlerden oluşmaktadır. İletişim kartlarının hazırlanırken örneklemin yaşı, dikkat süresi, ilgisi gibi özellikleri ve problem davranışların nesne elde etmek, zor görevden kaçmak olan işlevleri göz önünde bulundurulmuştur. İletişim kartları oluşturulurken uygulamalı davranış analizi ve işlevsel iletişim öğretimi alanında üç uzmanın görüşüne başvurulmuştur. Araştırmada koltuk resimli kart, yemek tabağı resimli kart, tablet bilgisayar resimli kart, lego resimli kart, etkinlik resimli kart ve tuvalet resimli 
kart şeklinde iletişim kartları oluşturulmuştur. Mola kartı, genişliği $21 \mathrm{~cm}$, yüksekliği 29.7 cm üst ve alt tarafında toplam 6 adet resimli kart (her bir kart $5 \times 6 \mathrm{~cm}$ ) olacak şekilde oluşturulmuştur. Mola kartının üst kısmına örneklemin temel fiziksel ihtiyaçlarını gidermek amaciyla oluşturulan tuvalet resimli kart, koltuk resimli kart ve yemek tabağ resimli kart yerleştirilmiştir. Alt kısmına ise örneklemin tercih edeceği akademik çalışmalar ve oyunlar olan tablet bilgisayarla oynama resimli kart, legolarla oynama resimli kart, çizgi çizme/resim boyama resimli kart yerleştirilmiştir.

Araştırmada kullanılacak pekiştireçlerin saptanması için araştırmacı tarafından Pekiştireç Belirleme Listesi hazırlanmış, örneklemin ailesiyle ve öğretmeniyle görüşmeler yapılmıştır. Örneklemin öğretmeni ve annesiyle pekiştireç belirleme listesi doldurulmuştur. Örneklemin pekiştireçler arasında en çok tercih ettikleri listelenmiştir. Buna ek olarak araştırmacının kaydettiği videolardan, öğretmenin kullandığı pekiştireçler ve örneklemin pekiştireçlere yönelimi belirlenmiştir. Pekiştireçlerin saptanması amacıyla yapılan bu değerlendirmelerde, örneklemin yiyecek - içecek pekiştireçlerine ilgi göstermediği görülmüştür. Sonuç olarak araştırmada sadece sosyal pekiştireçlerin (aferin - bravo - çok güzel yaptın ) kullanılmasına karar verilmiştir.

\section{İşlevsel İletişim Öğretim Programının Geliştirilmesi}

Araştırmada işlevsel iletişim programının geliştirilmesi, örneklemin problem davranışlarıyla aynı işleve sahip ve örneklemin pekiştireç elde etmesini sağlayan alternatif, daha uygun iletişim becerilerin kazandırılması sürecidir. İşlevsel iletişim öğretim programı geliştirilirken ilk olarak işlevsel değerlendirme yaparak davranışların işlevi belirlenmelidir (Durand, 1990). Bu araştırmada öğretim programı için ilk önce örneklemin problem davranışları belirlenmiş, problem davranışları ortaya çıkaran ve problem davranışlar üzerinde herhangi bir etkisi olmayan uyaranlar belirlenmiştir. Örneğin örneklemin etkinlik esnasında zorlanması, vurma davranışı üzerinde tetikleyici rol üstlenirken, aynı ortamda başka çocukların olmasının problem davranışlar üzerinde herhangi bir etkisi görülmemiştir. Örneklemin problem davranışlarının işlevleri nesne elde etmek ve zor görevden kaçmak olduğu görülmüştür. Araştırmada işlevsel değerlendirme sonucunda örneklemin davranışları ve çevresel değişkenler arasında bir bağlantı kurulmuştur. Bu değişkenlerin problem davranışlar üzerindeki etkisini ortaya koymak için işlevsel iletişim öğretim programı yapılmıştır. 


\section{Örneklemin Belirlenmesi ve Örneklem}

Örneklemin belirlenmesi süreci için ilk olarak araştırmacı tarafından geliştirilen “Aile Görüşme Formu” Bolu ilinde bulunan OSB tanısı konmuş yirmi üç çocuğun annesine uygulanmıştır. Buradaki amaç, OSB tanısı konmuş çocukların sergiledikleri problem davranışların neler olduğunun belirlenmesidir. Görüşme sonucunda, çalışmada gerekli görülen a) bir devlet hastanesinden OSB tanısı aldığına ilişkin onaylanmış sağlık raporuna sahip olmak, b) örneklemin gelişimini ve sosyal kabulünü olumsuz etkileyecek problem davranışlar görülmesi c) işlevsel iletişim öğretimine ilişkin öğretim almamış olmak ön koşul becerilerine sahip üç örneklem belirlenmiştir. Örneklem belirleme görüşmeleri sonucunda bir örneklem, ailesinin il değişikliği yapma ihtimali nedeniyle araştırmaya dahil edilmemiş, geriye kalan iki örneklemin birisiyle pilot uygulama, diğeriyle de gerçek uygulama yürütülmüştür. Araştırmada gerçek uygulamanın yürütüldüğü örneklem 11 yaşında, OSB tanısı almış bir erkek çocuğudur. Bir ilköğretim okulunda 4 yıldır özel eğitim almaktadır. Örneklem, anne-babasını ayırt edebilmekte, konuşan kişiye 9-14 saniye dikkatini verebilmekte, hayvan seslerini tanımaktadır. Rastgele sesler çıkarabilmekte, evet diyebilmekte, gösterilen hayvanların seslerini model olunduğunda çıkarabilmektedir. Örneklem, kaba motor becerilerde normal gelişim göstermektedir. İnce motor becerilerde ise; rastgele çizgi çizme, rastgele boyama yapma, makası tutma, legoları takma-çıkarma, kağıdı rastgele yırtma gibi daha alt becerileri gerçekleştirebilmektedir. Örneklem, bilişsel becerilerde nesneleri ana renklerine ve üçgen- kare olma özelliklerine göre eşleyebilmekte, nesneleri birbirinden boyut özelliklerine göre ayırt edebilmektedir ve adıyla seslenildiğinde tepki vermektedir.

\section{Pilot Uygulama}

Öğretim Programının uygulanmasında ortaya çıkabilecek sorunları önlemek, programa eklenmesi ya da programdan çıkarılması gereken noktaları belirlemek ve araştırmacının uygulamaya ilişkin pratik kazanması için çalışmada yer almayan başka bir örneklem ile pilot uygulama yürütülmüştür. Pilot uygulamasında elde edilen verilere göre, araştırmanın programında herhangi bir problem görülmemiş olup, programda bir değişiklik yapma gereği duyulmamıştır. 


\section{Başlama Düzeyi}

Araştırmada bağımsız değişken olan işlevsel iletişim öğretim süreci OSB olan bireye uygulanmadan önce çocuğun hedef problem davranışlarının görülme sıklı̆̆ verilerini elde etmek amacıyla başlama düzeyi evresi düzenlenmiştir. Başlama düzeyi evresinde verilerde üç oturum üst üste kararlılık elde edilinceye kadar oturumlar gerçekleştirilmiştir. Her oturum 15 dakika olacak şekilde tasarlanmış, oturumlarda bireyin ulaşabileceği şekilde "mola kartı" ve etkinlik kutuları yerleştirilmiş ve bireye ilk etkinlik olan legolar verilip tamamlaması için “önündeki legoları birleştir” yönergesi sunulmuştur. Lego etkiliğinden sonra, diğer etkinlikler sırayla tablet bilgisayar ve kağıt etkinleri olacak şekilde sunulmuş ve araştırmacı tarafından örnekleme yardım, müdahale veya ipucu sunulmamıştır.

\section{Uygulama Evresi}

Araştırmada işlevsel iletişim öğretiminin hazırlık aşamasında araç gereçler uygun yerlere yerleştirilmiş ve çevresel düzenleme sağlanmıştır. Öncelikle araştırmanın işlevsel iletişim kartları olan tuvalet resimli kartı, koltuk resim resimli kartı, yemek tabağı resimli kartı ve tablet bilgisayar resimli kartı, lego resimli kartı, etkinlik kağıdı resimli kartı; ayrıca etkinlik kutuları olan tablet bilgisayarın içinde bulunduğu kutu, kağıt etkinliklerin içinde bulunduğu kutu ve legoların içinde bulunduğu kutu odada bulunan masanın üzerine yerleştirilmiştir. Araştırmacı, örnekleme öğretime hazır hale getirmek için şimdi birlikte eğlenceli oyunlar oynayacağız, beni dinlemeni istiyorum. Eğer bana dikkatini verip dediklerimi yapar, söyle dediklerimi söylersen sevdiğin kağıtla ya da tablet bilgisayarla resim yapacaksın, çizgi çizeceksin, boyama yapacaksın ve legolarla oynayacaksın. Araştırmacı, örneklemin hazır olduğunu gördüğünde bir ihtiyacın yoksa başlayalım mı şeklinde söylemiş, örneklemin evet, başını sallama ya da bakma eylemlerinden sonra işlevsel iletişim kartlarını örnekleme öğretmeye başlamıştır.

Araştırmacı, ilk önce tuvalet resimli kartını örnekleme göstermiştir. Örnekleme “ bu tuvalet kartı, bu karta dokunman tuvalete gitmek istediğin anlamına gelir” demiştir. Araştırmacı, örneklemin göz kontağı kurması ve sandalyede oturmasını sosyal pekiştireçlerle pekiştirmiştir. Araştırmacı daha sonra koltuk resimli kartı ve yemek tabağı 
resimli kartı aynı mantıkla örnekleme tanıtmıştır. Araştırmacı işlevsel iletişim kartlarının tanıtılmasının ardından, öğretim esnasında kullanılması planlanan etkinlikleri örnekleme tanıtmıştır. Araştırmacı, ilk önce tablet bilgisayarı örnekleme göstererek, bu tablet bilgisayar etkinliğidir demiş. Eğer bunu seçersen tablet bilgisayarda çizgi çizme, boyama yapma veya şekil birleştirme etkinliklerinden bir tanesini birlikte yapacağız. Daha sonra lego resimli kartı ve etkinlik kağıdı resimli kartını örnekleme gösterip aynı mantıkla tanıtmıştır.

Öğretimde araştırmacı, örneklemin dikkatini çektikten sonra, örnekleme beceri yönergesi sunmuştur. "karta bak, yapmak istediğin etkinliği seç" demiştir. Örnekleme, iletişim kartında istediğini parmağıyla gösterdikten sonra, araştırmacı örneklemin işaret ettiği etkinliğin araç gereçleri önüne koymuştur. Beceri basamaklarını gerçekleştirmesini sağlayan "tablet bilgisayara bak çizgi çiz, önündeki tablet bilgisayara bak boyama yap, önündeki tablet bilgisayara bak şekilleri birleştir” gibi yönergeler sunmuştur. Araştırmac1, örneklemin mola vermek istediğini anladığında ( örneğin çocuğun etkinliğe olan ilgisinin azalması) model olup, koltuk resimli kartı parmağıyla göstermiştir. Daha sonra örneklemin da aynı davranışı gerçekleştirmesini sağlayıp “evet sen dinlenmek istiyorsun ve koltuk resimli kartı gösterdin 5 dakika dinlen” demiştir. Araştırmacı, diğer iletişim kartlarını aynı şekilde örnekleme öğretmiştir. Öğretim oturumları üç ortamda hafta içi her gün ve günde iki oturum olacak şekilde yürütülmüştür. Her oturum 15 dakika olarak düzenlenmiştir. Oturumlar video kameraya alınmıştır. Birinci ortamda (ev ortamında), hedef davranışlarda ölçüt karşılanıp üç oturum üst üste kararlı veri elde edildikten sonra tüm hedef davranışlar için üç farklı ortamda (ev ortamında, sınıf ortamında ve spor salonunda) eşzamanlı olarak ikinci yoklama evresi düzenlenmiştir. Tüm ortamlarda, üç oturum üst üste sürekli kararlı veri elde edinceye değin yoklama evresinde veri toplanmıştır. Yoklama verisinde üç oturum üst üste kararlı veri elde edildikten sonra ikinci ortam olan sınıf ortamında ve üçüncü ortam olan spor salonunda aynı şekilde öğretimler yürütülmüştür. Uygulama verileri tamamlandıktan sonra izleme evresine geçilmiştir.

Araştırmacı uygulama esnasında örnekleme yönerge verdikten sonra yaklaşık 3-5 saniye beklemiş, örneklem becerilerini yerine getirmediği zaman araştırmacı uygun yardım ipucunu sunmuştur. Örneğin örneklem tablet bilgisayar üzerinde şekilleri eşleştirme yaparken, beceriyi uygun şekilde gerçekleştirmediği zaman araştırmacı, örneklemin elinden tutup nasıl uygun şekilde eşlemeyi yapacağını göstermiştir. 
Araştırmac1, örneklemin diğer etkinlikleri gerçekleştirmesinde benzer şekilde yardımlar ile nasıl yapacağını göstermiştir. İşlevsel iletişim öğretimi oturumlarında katılımcının etkinliği yarıda kesip problem davranış sergilediği zamanlarda, araştırmacı herhangi bir pekiştirme uygulamamış, örneklemin problem davranışların alternatifi olan iletişim kartını kullanması durumunda ise hemen sosyal pekiştireçlerle olumlu davranışı pekiştirmiştir. Ayrıca örneklemin ısırma ve vurma davranışlarını sergilemesi esnasında ise araştırmacı, örneklemin ellerinden tutup yerine oturtması için fiziksel müdahalede bulunmuştur. Uygulamalar esnasında örneklemin sergilediği problem davranışlar ayrı ayrı olay kaydı formlarına işaretlenmiş ve analiz kısmında ortalamalarına hesaplanarak grafiğge işlenmiştir.

\section{Öğretimde ipuçlarının silikleştirilmesi.}

İşlevsel iletişim öğretimi oturumlarında silikleştirme, örnekleme sunulan yardımlar ve ipuçlarının araştırmacı tarafından kademeli olarak geri çekilmesiyle sağlanmıştır. Örnekleme etkinlikleri gerçekleştirmesi için sağlanan fiziksel yardımlar sırasıyla model olma, sözel ipucu ve bağımsız olacak şekilde silikleştirilmiştir. İpuçlarının geri çekilmesi, öğretim oturumları sırasında örneklemin beceriyi gerçekleştirmesine göre araştırmacı tarafından kararlaştırılmıştır. Öğretim oturumlarında örneklemin mola isteme sıklığını azaltmak ve etkinlikle daha fazla ilgilenmesi sağlamak amacıyla iletişim kartına ulaşması zamanla silikleştirilmiştir. Öğretim oturumlarında "mola kartı" ilk başlarda örneklemin hemen yanına konulurken, zamanla örneklemden daha uzak bir yerde tutulmuştur. Örneklemin normal etkinliğini gerçekleştirme süresi ve sıklığı giderek arttırılmış ve basit olan etkinliklerin süresi ve sıklığı ise oturumlarda daha da azaltılmıştır.

\section{İzleme oturumları.}

Öğretim oturumları tamamlandıktan sonra örneklemin problem davranışlarıyla aynı işleve sahip olan iletişim becerilerini tercih etme, işlevsel etkinlikleri gerçekleştirme ve etkinlikle zaman geçirme kazanımlarını koruyup korumadığını tespit etmek amacıyla izleme oturumları gerçekleştirilmiştir. İzleme oturumları, öğretim oturumlarında gerçekleştirilen uygulamalarda herhangi bir farklılığa gidilmeden benzer oturumlar şeklinde düzenlenmiştir. İzleme oturumları, öğretim oturumlarının gerçekleştirildiği aynı ortamlarda yapılmıştır. İzleme oturumları esnasında, örneklem hedeflerin tümünü yerine getirdikten sonra örneklemin davranışları sosyal pekiştireçlerle pekiştirilmiştir. 


\section{Verilerin Toplanması ve Analizi}

Araştırmada etkililik, sosyal geçerlilik ve güvenirlik verisi olmak üzere üç tür veri toplanmış ve analiz edilmiştir.

\section{Etkililik verilerinin toplanması ve analizi.}

Araştırmada etkililik verileri, öğretim sürecinin tamamını ve tüm ortamları içerecek şekilde videoya kaydedilerek toplanmıştır. Araştırmada, örneklemin etkinlikle ilgilenme süresini belirlemek için toplanan veriler süre kaydı formuna işlenmiş, bir oturum sonucunda örneklemin etkinlikle ilgilenme süresi belirlenmiş ve grafiğe aktarılmıştır. Örneklemin oturumlar esnasında sergilediği problem davranışlar ise olay kaydı formuna işaretlenmiş, benzer şekilde grafiğe aktarılmıştır.

Araştırmada veriler, grafiksel analiz yoluyla analiz edilmiştir. Araştırmada elde edilen veriler tek bir grafik üzerinde incelenmiştir. Üç ayrı problem davranışın yüzdeleri alınarak grafik üzerinde tek bir eğride ele alınmıştır. Örneklemin, gözlem aralıklarında problem davranışları sergileme sıklığı grafiğe aktarılmış ve toplam geçen süreye bölünüp yüzdesi hesaplanmıştır. Üç problem davranış için bu süreç yürütüldükten sonra problem davranışların ortalama görülme sıklığı toplanıp yüzdesi bulunmuştur. Örneklemin gözlem süresince etkinlikle ilgilenme süresi grafiğe işlenmiş olup, yüzdesi ortaya konulmuştur.

\section{Sosyal geçerlik verilerinin toplanması ve analizi.}

Araştırmada kullanılan yöntemin işlevselliğini ortaya koymak amacıyla iki farklı sosyal geçerlilik formu araştırmacı tarafından geliştirilmiştir. İlki örneklemin ebeveynlerine ikincisi ise alanda çalışan öğretmenlere uygulanacak şekilde açık uçlu sorulardan oluşan form düzenlenmiştir. Örneklemin ebeveynlerine, örneklemin performansına yönelik kayıtların bulunduğu bir CD ve ebeveynlerin görüşlerini ortaya koymak için hazırlanan soru formu aileye verilmiştir. Benzer şekilde öğretmenlere araştırmanın özeti, soru formu ve bir CD hazırlanıp, teslim edilmiştir. Elde edilen veriler betimsel analiz yöntemiyle deşifre edilmiştir.

\section{Araştırma verilerinin güvenirliği.}


Araştırma verilerinin güvenirliği; (a) gözlemciler arası güvenirlik ve (b) uygulama güvenirliği şeklinde sunulmuştur. Araştırmada gerçekleştirilen başlama düzeyi, öğretim, toplu yoklama ve izleme oturumlarının en az \%30'unda gözlemciler arası güvenirlik ve uygulama güvenirliğine yönelik veri toplanmıştır. Araştırmada güvenirlik, özel eğitim alanında yüksek lisans yapan özel eğitim öğretmeni olan bir uzmanın katkılarıyla sağlanmaya çalışılmıştır. Örneklemin araştırma ortamlarına ilişkin video kayıtları tüm oturumlar için aynı kişi tarafından izlenmiştir. Araştırmada yansız atama yoluyla tüm oturumların en az \%30’u seçilmiş ve gözlemciler arası güvenirlik ve uygulama güvenirliği verisi incelenmiştir.

\section{Gözlemciler arası güvenirlik verilerinin toplanması ve analizi.}

Gözlemciler arası güvenirlik verileri yoklama, öğretim ve izleme oturumlarında toplanmıştır. Gözlemciler arası güvenirlik verileri “ İşlevsel İletişim Öğretim Sürecine İlişkin Yoklama ve İzleme Oturumları Veri Toplama Formu’na”, “ İşlevsel İletişim Becerilerin Öğretim Sürecine İlişkin Günlük Yoklama Oturumları Veri Toplama Formu’na” ve “ İşlevsel İletişim Becerilerin Öğretim Sürecine İlişkin Öğretim Oturumları Veri Toplama Formu'na” kaydedilmiştir. Araştırmacı ve gözlemci her bir öğretim oturumunu problem davranışlar ve etkinlikle ilgilenme sıklığı belirlemek amacıyla incelemiştir. Her oturum ilk önce problem davranışları belirlemek amacıyla izlenmiş ve veriler forma aktarılmış daha sonra aynı oturum etkinlikle ilgilenme davranışların süresini belirlemek için izlenmiş ve veriler forma işlenmiştir.

Gözlemciler arası güvenirlik hesaplaması, uygulamacı ve gözlemcinin elde ettiği veriler doğrultusunda “ Görüş birliği / (Görüş Birliği + Görüş Ayrıllğ 1 ) × 100 formülü kullanılarak hesaplanmıştır (Tekin-İftar ve Kırcaali-İftar, 2006). Araştırmada her bir ortam için yoklama, izleme ve genelleme oturumlarında elde edilen gözlemciler arası güvenirlik katsayısı \%100 olarak bulunmuştur. Gözlemciler arası güvenirlik verileri şu şekildedir:

Tablo 3.1. Gözlemciler arası güvenirlik verileri

\begin{tabular}{lllllll}
\hline Beceri & Uygulama & B.D. & Öğretim & T.Y. & Genelleme & İzleme
\end{tabular}

\section{Etkinlikle}

İlgilenme

Video

$100 \quad 100$

100

100

100 
YYÜ Eğitim Fakültesi Dergisi (YYU Journal of Education Faculty), 2021;18(2)152-182,http://efdergi.yyu.edu.tr,

\section{Problem}

Davranıs

Video

$100 \quad 100$

90

100

100

Anahtar: B.D.: Başlama Düzeyi Yoklama

T.Y.: Toplu Yoklama

\section{Uygulama güvenirliği verilerinin toplanması ve analizi.}

Uygulama güvenirliği verileri, öğretim ve izleme oturumlarında toplanmıştır. Veriler “İşlevsel İletişim Öğretim Sürecine İlişkin Yoklama ve İzleme Oturumları Uygulama Güvenirliği Veri Toplama Formu’na” ve “İşlevsel İletişim Öğretim Sürecine İlişkin Öğretim Oturumları Uygulama Güvenirliği Veri Toplama Formu’na” kaydedilmiştir. Yoklama ve izleme oturumlarında uygulama güvenirliği için veriler toplanırken araştırmacının a) araç gereçleri hazırlama, b) ortam düzenlemesi yapma, c) ipucu sunma, d) yönerge sunma, e) örneklemin problem davranışlarını görmezden gelme, f) örneklemin etkinliğe katılımını pekiştirme davranışları göz önünde bulundurulmuştur. Öğretim oturumlarında uygulama güvenirliği verileri için de veriler toplanırken araştırmacının a) araç gereçleri hazırlama, b) ortam düzenlemesi yapma, c) ipucu sunma, d) yönerge sunma, f) örneklemin problem davranışlarını görmezden gelme, g) kontrol edici ipucu sunma, h) örneklemin etkinliğe katılımını pekiştirme davranışları değerlendirilmiştir.

Gözlemcinin topladığı veriler doğrultusunda (Gözlenen Uygulamacı Davranışı / Planlanan Uygulamacı Davranışı) × 100 formülü kullanılarak araştırmanın uygulama güvenirliği hesaplanmıştır (Tekin-İftar ve Kırcaali-İftar, 2006 ). Uygulama güvenirliği verileri şu şekildedir:

Tablo 3.2 Uygulama güvenirliği verileri

\begin{tabular}{llcccc}
\hline Beceri & Uygulama & B.D. & Öğretim & T.Y. & İzleme \\
\hline $\begin{array}{l}\text { Araç-gereçleri } \\
\text { hazırlama }\end{array}$ & Video & 100 & 88 & 100 & 100 \\
$\begin{array}{l}\text { İpucu sunma } \\
\text { Video }\end{array}$ & 100 & 100 & 100 & 100 \\
Yönerge sunma & Video & 100 & 100 & 90 & 100
\end{tabular}


YYÜ Eğitim Fakültesi Dergisi (YYU Journal of Education Faculty), 2021;18(2)152-182,http://efdergi.yyu.edu.tr,

doi:10.33711/

Araștırma Makalesi

ISSN: 1305-2020

Problem davranıșlara Video

100

100

100

100

doğru müdahale etme

Anahtar: B.D.: Başlama Düzeyi Yoklama

T.Y.: Toplu Yoklama 
YYÜ Eğitim Fakültesi Dergisi (YYU Journal of Education Faculty), 2021;18(2)152-182,http://efdergi.yyu.edu.tr,

\section{Bulgular}

Araştırmanın bu kısmında, işlevsel değerlendirme, etkililik, izleme ve sosyal geçerlilik bulgularına yer verilmiştir.

\section{İşlevsel İletişim Öğretimin Etkililiğine Yönelik Bulgular}

İşlevsel iletişim öğretimin etkililiğine ilişkin bulgular şekil 4.1'de verilmiştir. Bu grafikte başlama düzeyi, uygulama ve izleme oturumlarında problem davranışlarının ve etkinlikle ilgilenme davranışlarının izlendiği gözlem aralıklarının yüzdesine yer verilmiştir. Grafik üzerinde yatay eksen oturum sayısını, düşey eksen ise örneklemin tepki yüzdelerini göstermektedir. Araştırmada elde edilen veriler şekil 4.1 grafiğinde, başlama düzeyi, yoklama, uygulama ve izleme oturumları olmak üzere dört evrede sunulmuştur.

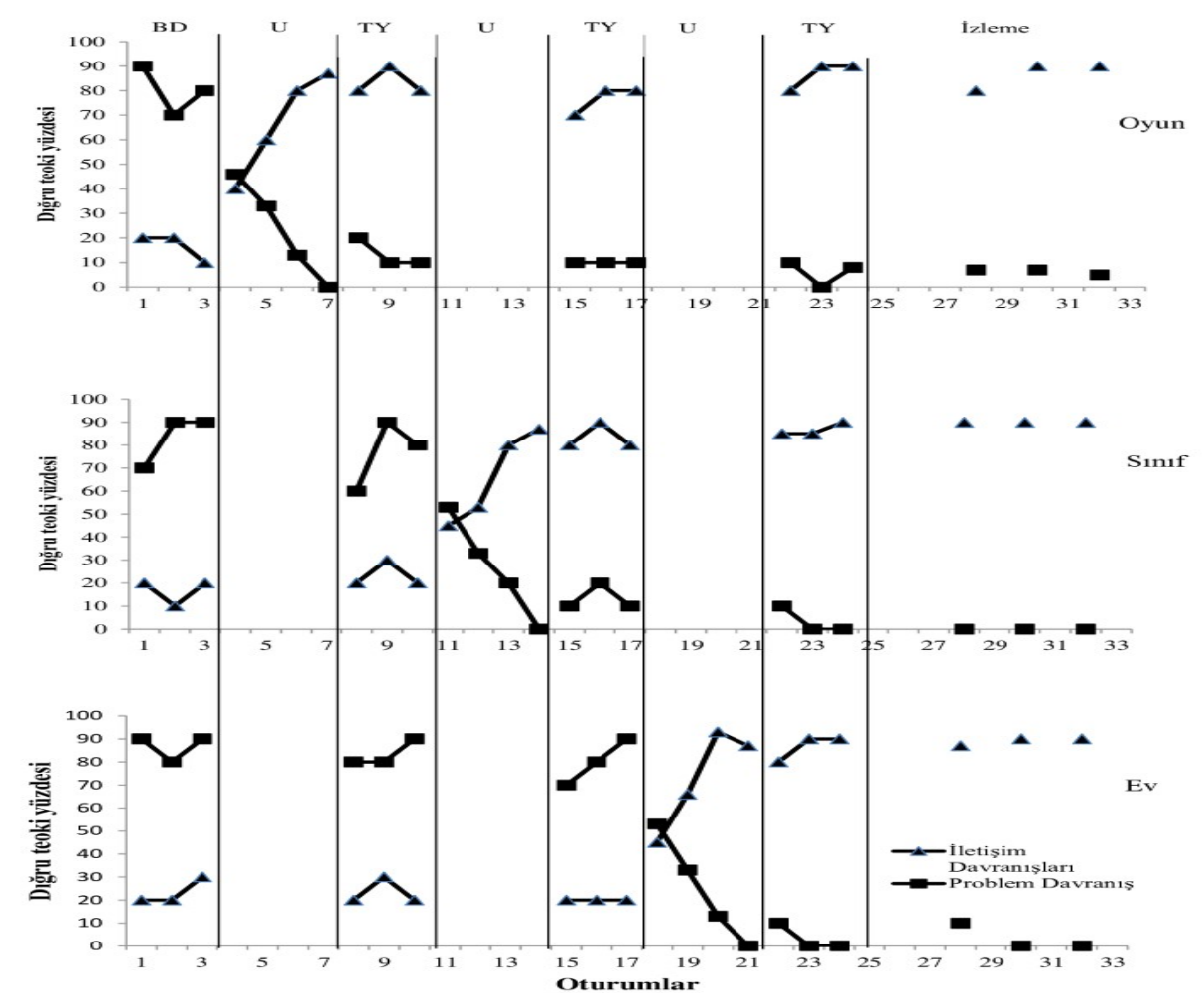

Şekil 4.1. Örneklemin problem davranışları ve etkinlikle ilgilenme davranışlarına yönelik başlama düzeyi, uygulama, toplu yoklama ve izleme oturumları 
Şekil 4.1'de işlevsel iletişim öğretimin gerçekleştirildiği oturumlarda örneklemin problem davranış oranının düştüğü ve etkinlikle ilgilenme davranışlarında artış olduğu görülmektedir. Örneklemin oyun odasında başlama düzeyi verilerinde, problem davranışların gözlem aralıklarının yüzdesinin ortalaması \%80 düzeyindeyken; etkinlikle ilgilenme davranışlarının görüldüğü gözlem aralıklarının yüzde ortalaması \%16.66 olarak görülmüştür. Sınıf ortamında başlama düzeyi verilerinde, problem davranışların gözlem aralıklarının yüzdesinin ortalaması \%83.33 düzeyindeyken; etkinlikle ilgilenme davranışlarının görüldüğü gözlem aralıklarının yüzde ortalaması \%15’tir. Örneklemin ev ortamında başlama düzeyi verilerinde, problem davranışların gözlem aralıklarının yüzdesinin ortalaması $\% 90$ düzeyindeyken; etkinlikle ilgilenme davranışlarının görüldüğü gözlem aralıklarının yüzde ortalaması \%17 olduğu görülmektedir. Üç ayrı ortamda başlama düzeyi verileri üç oturum üst üste sürekli kararlı veri elde edildikten sonra birinci ortam olan oyun odasında uygulama gerçekleştirilmiştir. Örneklemin birinci ortamda uygulama evresinde, problem davranışların görüldüğü gözlem aralıklarının yüzde ortalaması \%23 iken; etkinlikle ilgilenme davranışlarının görüldüğü gözlem aralıklarının yüzde ortalaması \%66 olarak ortaya konulmuştur. Örneklem birinci uygulama ortamında üç oturum üst üste sürekli kararlı veri ettikten sonra, üç ayrı ortam için toplu yoklama verisi alınmıştır. Örneklemin oyun odasında birinci toplu yoklama verilerinde, problem davranışların gözlem aralıklarının yüzdesinin ortalaması \%13.33 düzeyindeyken; etkinlikle ilgilenme davranışlarının görüldüğü gözlem aralıklarının yüzde ortalaması \%83 olarak görülmüştür. Sınıf ortamında birinci toplu yoklama verilerinde, problem davranışların gözlem aralıklarının yüzdesinin ortalaması $\% 76.66$ düzeyindeyken; etkinlikle ilgilenme davranışlarının görüldüğ̈ gözlem aralıklarının yüzde ortalaması \%16 olduğu görülmüştür. Örneklemin ev ortamında birinci toplu yoklama verilerinde, problem davranışların gözlem aralıklarının yüzdesinin ortalaması \%83.33 düzeyindeyken; etkinlikle ilgilenme davranışlarının görüldüğ̈ gözlem aralıklarının yüzde ortalaması \%16 olduğu bulgulanmıştır. Üç ayrı ortamda toplu yoklama verileri alındıktan sonra ikinci ortam olan sınıf ortamında uygulama gerçekleştirilmiştir. Örneklemin sınıf ortamında işlevsel iletişim öğretimin gerçekleştiği uygulama evresinde, problem davranışlarının görüldüğü gözlem aralıklarının yüzde ortalaması \%26.5 iken; etkinlikle ilgilenme davranışlarının görüldüğ̈̈ gözlem aralıklarının yüzde ortalaması \%66.25 olarak kaydedilmiştir. İkinci uygulama ortamında üç oturum üst üste sürekli kararlı veri elde edildikten sonra üç ayrı ortam için toplu yoklama verisi alınmıştır. Örneklemin oyun 
odasında ikinci toplu yoklama verilerinde, problem davranışların gözlem aralıklarının yüzdesinin ortalaması \%10 düzeyindeyken; etkinlikle ilgilenme davranışlarının görüldüğü gözlem aralıklarının yüzde ortalaması \%76 olarak tespit edilmiştir. Sınıf ortamında ikinci toplu yoklama verilerinde, problem davranışların gözlem aralıklarının yüzdesinin ortalaması \%13.33 düzeyindeyken; etkinlikle ilgilenme davranışlarının görüldüğü gözlem aralıklarının yüzde ortalaması \%83 olarak kaydedilmiştir. Örneklemin ev ortamında ikinci toplu yoklama verilerinde, problem davranışların gözlem aralıklarının yüzdesinin ortalaması $\% 80$ düzeyindeyken; etkinlikle ilgilenme davranışlarının görüldüğü gözlem aralıklarının yüzde ortalaması \%20 olduğu görülmüştür. Üç ayrı ortamda toplu yoklama verileri alındıktan sonra üçüncü ortam olan ev ortamında uygulama yapılmıştır. Örneklemin ev ortamında işlevsel iletişim öğretiminin gerçekleştiği uygulama evresinde, problem davranışların görüldüğü gözlem aralıklarının yüzde ortalaması \%24.75 iken; etkinlikle ilgilenme davranışlarının görüldüğü gözlem aralıklarının yüzde ortalaması \%72 olduğu görülmektedir. Örneklemin üçüncü uygulama ortamında üç oturum üst üste sürekli kararlı veri edildikten sonra, üç ayrı ortam için toplu yoklama verisi alınmıştır. Örneklemin oyun odasında üçüncü toplu yoklama verilerinde, problem davranışların gözlem aralıklarının yüzdesinin ortalaması \%6 düzeyindeyken; etkinlikle ilgilenme davranışların görüldüğ̈̈ gözlem aralıklarının yüzde ortalaması \%86.66 olarak görülmüştür. Sınıf ortamında üçüncü toplu yoklama verilerinde, problem davranışların gözlem aralıklarının yüzdesinin ortalaması \%0 düzeyindeyken; etkinlikle ilgilenme davranışlarının görüldüğü gözlem aralıklarının yüzde ortalaması \%90 olarak kaydedilmiştir. Örneklemin ev ortamında üçüncü toplu yoklama verilerinde, problem davranışların gözlem aralıklarının yüzdesinin ortalaması \%3.3 düzeyindeyken; etkinlikle ilgilenme davranışlarının görüldüğü gözlem aralıklarının yüzde ortalaması \%90 olduğu izlenmektedir. Üç ayrı ortamda toplu yoklama verileri alındıktan sonra üç ortam için izleme verileri alınmıştır.

\section{İşlevsel İletişim Öğretimin Etkililiğine İlişsin İzleme Bulguları}

Araştırmanın öğretim oturumları bittikten sonra da davranışların sürdürülüp sürdürülmediğinin ortaya konulması amacıyla izleme oturumları düzenlenmiştir. İzleme oturumlar1, son öğretim oturumundan 2, 4 ve 6 gün sonra düzenlenmiştir. Her üç uygulama ortamında bir izleme denemesine yer verilmiştir. İzleme bulguları Şekil 4.1'de sunulmuştur. İzleme oturumlarındaki verilere bakıldığında, örneklemin oyun odasında 
izleme evresinde, problem davranışların gözlem aralıklarının yüzde ortalaması \%6.3 iken; etkinlikle ilgilenme davranışlarının gözlem aralıklarının yüzde ortalaması \%86.66 olarak kaydedilmiştir. Sınıf ortamında izleme evresinde, problem davranışların gözlem aralıklarının yüzde ortalaması \%0 iken; etkinlikle ilgilenme davranışların gözlem aralıklarının yüzde ortalaması \%90 olduğu görülmektedir. Ev ortamında izleme evresinde, problem davranışların gözlem aralıklarının yüzde ortalaması \%3.3 iken; etkinlikle ilgilenme davranışların görüldüğü gözlem aralıklarının yüzde ortalaması \%89 olduğu görülmektedir.

\section{İşlevsel İletişim Öğretimin Etkililiğine İlişkin Sosyal Geçerlilik Bulguları}

Araştırmada kullanılan yöntemin işlevselliğini ortaya koymak amacıyla araştırmacı tarafından geliştirilen iki farklı sosyal geçerlilik formu yoluyla örneklemin ebeveynleri ve öğretmeninden görüş alınarak çalışmanın sosyal geçerliği incelenmiştir. Örneklemin ebeveynleri ve öğretmenine ilk olarak “ Sizce araştırmacı, sözleşmede ortaya konulan sorumlulukları gerçekleştirmiş midir?” sorusu yöneltilmiştir. Örneklemin bu soruya; evet ve kesinlikle yanıtlarını verdikleri görülmüştür. Örneklemin babası “çocuğumla ilgilenen hocamızın büyük bir titizlikle sonuna kadar kurallara uyduğunu rahatlıkla söyleyebilirim” şeklinde bu konuda ki görüşünü belirtmiştir.

Örneklemler yöneltilen ikinci soru, “Araştırmada, uygulama koşullarını, ortamını, araç ve gereci uygun buldunuz mu?” olmuştur. Örneklemlerin tümü $(n=3)$ cevaplarında uygulama koşulları, ortam, araç ve gereçlerin uygunluğundan bahsetmiştir. Örneklemin annesi "bir öğretmen olarak uygulama için gerekli düzenlemelerin yerli yerinde olduğu gözlemledim” şeklinde görüş belirtirken; örneklemin öğretmeni ise "seçilen üç ortam ve materyallerin öğrencimin dikkatini bu kadar çekeceğini düşünmemiştim. Benim için de çok faydalı olduğunu düşünüyorum. Özellikle sınıf ortamında çalışmalar gerçekleştirildiğinde gözlem uzaktan gözlem yapma şansı buldum. Bana çok şey kattı̆̆ııı gördüm” şeklinde görüşlerini açıklamıştır.

Örnekleme üçüncü olarak “Öğrencinizde ele alınan problem davranışların öncelikli ortadan kaldırılması gereken davranış olduğunu düşünüyor musunuz?” sorusu yöneltilmiştir. Örnekleminin tümü $(n=3)$ cevaplarında örneklimin ele alınan problem davranışlarının öncelikli değiştirilmesi gerektiğini ifade etmişlerdir. Örneklemin annesi "evde çok zor zamanlar geçiriyoruz. Eşim kapı ve pencere kollarını sökmüs ve yerine 
YYÜ Eğitim Fakültesi Dergisi (YYU Journal of Education Faculty), 2021;18(2)152-182,http://efdergi.yyu.edu.tr,

ISSN: 1305-2020

kilitlenebilen aparatlar takmış durumdadır. Ŏglum çok problemli davranışlar sergiliyordu $ı l ı$ hatta halen devam eden bazı davranışları söz konusudur. Hocamızla çalıştıkları davranışlar gerçekten çok önemli ve hemen değişmesini istediklerim arasında olanlardl” şeklinde bu konuda ki görüşlerini ifade etmiştir. Örneklim öğretmeni “sınıf ortamında dersin akışını zora sokan davranışların çalışıldı̆̆ını söyleyebilirim. Bundan sonra benim bu kazanımları sürdürmem sınıf ortamı için faydalı olacaktır. Çünkü sınıfımda problem davranışları olan toplam üç ögrenci var” şeklinde görüşlerini açıklamıştır.

Bir sonraki soruda örneklemlere "işlevsel iletişim öğretiminin problem davranışları söndürdüğünü düşünüyor musunuz?” sorusu yöneltilmiştir. Örnekleminin tamamı ( $\mathrm{n}=3$ ) cevaplarında araştırma örneklemini göz önünde bulundurarak evet yanıtını vermişlerdir. Örneklemin babası "daha önce duymadı̆̆ım ve bilmediğim bir yöntem ama çocuğumda gözlemlediğim kadarıla çok etkili olduğunu söyleyebilirim” şeklinde görüş belirtirken örneklemin annesi ise "ben sınıf öğretmeniyim, oğlumun gelişimi için birçok ĕ̌itim aldı̆̆ımı da söyleyebilirim. Bu yöntemi hiç duymamıştım. İlk defa hocamız çalışınca bize detaylı anlattı. Sabırsızlıkla sonuçlarını bekliyordum. Çok etkili olduğunu söyleyebilirim” şeklinde görüş belirtmiştir.

Örneklemlere beşinci olarak "bu yöntemi kullanarak farklı becerileri öğretmeyi düşünür müsünüz?” sorusu sorulmuştur. Örneklemlerden ikisi evet yanıtını verirken bir tanesi (örneklemin babası) ise çok iyi bir yöntem ama ben yapabileceğimi sanmıyorum şeklinde yanıt vermiştir.

Örneklemlere yöneltilen bir sonraki soru "sizce araştırmada kullanılan yöntem ile örneklemin problem davranışları arasında işlevsel ilişki kurulmuş mudur?” sorusu olmuştur. Örnekleminin tamamı $(\mathrm{n}=3)$ cevaplarında işlevsel ilişkinin kurulduğunu belirtmişlerdir. Bu konu hakkında örneklemin babası "araştırmaya ilk başlandığı günü hatırlıyorum. Iı şimdi düşündüğ̈̈̈mde ve sonucu ele aldiğımda kesinlikle neden ve sonucu görebiliyorum” şeklinde ki görüşlerini aktarmıştır. Örneklemin öğretmeni ise "öğrencimin sınıf ortamında ki davranışlarını, teneffüsleri veya serbest zaman etkinliklerde ki davranışlarını düşündügümde problem davranışları ve işlevsel iletişim öğretimi arasında bir ilişki var” şeklinde görüş belirtmiştir. 
YYÜ Eğitim Fakültesi Dergisi (YYU Journal of Education Faculty), 2021;18(2)152-182,http://efdergi.yyu.edu.tr,

Örneklemlere son olarak “öğrencinize araştırmada kazandırılan işlevsel becerilerin derslerde sergilediğini gözlemlediniz mi?” sorusu yöneltilmiştir. Örnekleminin ikisi (annesi ve öğretmeni) cevaplarında becerilerin derslerde de kullanıldığını ifade ederken, biri (babası) tam gözlem yapma şansı olmadığını şeklinde cevaplamıştır. Örneklemin annesi “ögrretmeniyle her gün konuşuyoruz. Oğlumun her türlü davranışlarını merak ediyor ve öğretmeniyle iletişime geçiyorum. Çalışılan becerilerin derslerde sergilendiğini ögrretmeni tarafindan duyuyorum” şeklinde görüş belirtirken; örneklemin babası "daha çok annesi ilgilendiği için gözlem şansım olmadı. Aslında ben de gidip takip etmeyi çok isterim amcak akademisyen olmanın verdiği yoğunluk bunu çoğu zaman engelliyor maalesef” şeklinde görüşlerini aktarmıştır.

\section{Tartışma ve Sonuç}

Araştırmanın birinci kategorisinde işlevsel iletişim öğretimin, ilgili alanyazına paralel olarak OSB olan bireylerin problem davranışlarının ortadan kaldırılmasında ve bu bireylerin etkinlikle ilgilenme davranışları üzerinde etkili olduğu görülmüştür. Araştırmada işlevsel iletişim öğretim programı hazırlanırken örneklemin problem davranışları ile bu davranışları sürdüren değişkenler ortaya konulmuştur. Carr ve Carlson (1993) problem davranışlar ve davranışların işlevlerini belirlemek için deneysel-betimsel tekniklerin bir arada kullanılmasını önermişlerdir. $\mathrm{Bu}$ araştırmada da işlevsel değerlendirme için doğrudan gözlemler, öğretmen ve ebeveyn görüşmelerinden elde edinilen veriler kullanılmıştır. Araştırmada, katılımıının problem davranışlarıyla benzer işlev gösteren becerilerin kullanılması ve örneklemin bu becerilere ilgi göstermesi O’Brien ve diğerleri (2021) araştırma sonuçlarıyla benzerlik göstermektedir. Ayrıca Durand (1999) araştırmasında, beş örneklemin problem davranışları ve bu davranışların işlevlerini belirlemiştir. Bu işlevleri zor görevden kaçmak, nesne elde etmek ve dikkat çekmek olarak ortaya koymuştur. İşlevsel değerlendirme sonucunda, örneklemlerin problem davranışlarını sürdüren değişkenlerin yerine alternatif iletişim becerileri öğretmiştir. Araştırma sonucunda okuldan kaçma davranışları ortadan kalkan örneklemlerde, etkinlikle ilgilenme davranışlarında artış gözlenmiştir. Benzer bir şekilde bu araştırmada da örneklemin problem davranışlarının işlevlerine uygun olarak seçilen işlevsel becerilerin öğretiminden sonra örneklemde problem davranışların ortadan kalktığı ve örneklemin etkinlikle ilgilenme süresinin artığı görülmüştür. İfade edici dil becerisi yeterince gelişmemiş OSB'li bireylerde tercih edilen kartlar bu araştırma örneklemi için 
de kullanılmıştır. Araştırmada örneklemin nesne elde etmek, kaçmak/kaçınmak amacıyla sergilediği problem davranışlarına alternatif olarak "Mola Kartı" kullanılmış ve araştırma sonucunda örneklemin iletişim becerilerini kazandığı problem davranışlarının ise ortadan kalktığı görülmüştür. Benzer bir şekilde Hagopian, Contrucci, Kuhn, Long ve Rush (2005), OSB tanılı üç örneklem ile araştırma yürütmüşlerdir. Araştırmada örneklemlerin problem davranışları saldırganlık, kendine zarar verme ve yıkıcı davranışlar olarak belirlenmiştir. İşlevsel değerlendirmeyle problem davranışların işlevleri dikkat elde etme ve etkinlik elde etme şeklinde ortaya konulmuştur. İşlevsel iletişim becerisi olarak "konuşmak istiyorum" resimli kartını vermek olarak kararlaştırmışlardır. Hagopian ve diğerlerinin (2005) araştırma sonucunda işlevsel iletişim öğretimin problem davranışları ortadan kaldırılmasında etkili olduğu ve problem davranışları ortadan kalkan örneklemlerin etkinlikle ilgilenme sürelerinde artış olduğunu ifade etmişlerdir. Araştırma sonuçları, işlevsel iletişim öğretimin problem davranışları ortadan kaldırdığını göstermektedir. İşlevsel iletişim öğretimin uygulandığı oturumlarda örneklemin problem davranışlarının başlangıç düzeyi oturumlarına göre daha az meydana geldiği görülmüş ve iletişim davranışlarının da daha fazla sergilendiği ortaya konulmuştur. Bu araştırmanın sonuçlarına bakılarak problem davranışların işlevleriyle benzer işlevi olan iletişim becerilerin öğretilmesinin, problem davranışlar üzerinde olumlu sonuçları söylenebilir. Araştırmanın etkililik sonuçlarına baktığımızda, benzer şekilde problem davranışların ortadan kaldırılmasında işlevsel iletişim öğretimin etkilerini araştıran araştırmaların sonuçlarıyla benzerlik gösterdiği görülmektedir.

Araştırmanın ikinci kategorisinde işlevsel iletişim öğretimin etkililiğine ilişkin izleme verilerinde, alanyazındaki sonuçlara benzer olarak OSB olan bireylerin problem davranışlarının ortadan kaldırılmasında ve bu bireylerin etkinlikle ilgilenme davranışları üzerinde etkili olduğu, öğretim programı sona erdikten sonra da kazanılan davranışların sürdürüldüğü görülmüştür. Araştırmada izlemeye yönelik ortaya konulan bu sonuçlar Gerow, Radhakrishnan, Davis Hodges ve Feind, (2020) ile Fisher, Adelinis, Thompson, Worsdell ve Zarcone (1998) araştırma sonuçlarıyla benzerlik göstermektedir. Fisher, Adelinis, Thompson, Worsdell ve Zarcone (1998) zor görevlerin bireylerde etkinlikleri yarıda bırakmaya neden olduğunu ifade etmişlerdir. Ayrıca bireylerin etkinlikler esnasında problem davranış göstermeleri, etkinliklerin akışını bozduğu söylemişlerdir. Araştırmada, işlevsel iletişim öğretim oturumları tamamlandıktan sonra örneklemin 
kazanılan becerileri sürdürdüğünü ifade etmişlerdir. Araştırma sonuçları işlevsel iletişim öğretim oturumları sona erdikten sonra da kazanılan becerilerin sürdüğünü ve işlevsel iletişim öğretiminin problem davranışlar üzerinde etkili bir yöntem olduğunu göstermektedir. Braithwaite ve Richdale, (2000) kendisine ve başkasına vurma şeklinde problem davranışları olan OSB'li bir bireyle iletişim becerilerin çalışılması sonunda, problem davranışların ortadan kalktığını ve öğretim sona erdikten sonra da kazanılan becerilerin sürdürüldüğünü görmüşlerdir. Worsdell, Iwata, Hanley, Thompson ve Woo Kang (2000) kendine zarar verme davranışı ve saldırganlık davranışları olan beş örneklemle sönme tekniğine yer vermeden işlevsel iletişim öğretimin etkilerini araştırmışlardır. Sonuçta, işlevsel iletişim öğretimin bireylerin problem davranışlarını ortadan kaldırdığını ve iletişim becerilerini kullanma oranını arttığını ortaya koymuşlardır.

Araştırmanın üçüncü kategorisinde işlevsel iletişim öğretimin etkililiğine ilişkin sosyal geçerlik verilerinde, alanyazındaki sonuçlara benzer olarak OSB olan bireylerin problem davranışlarının ortadan kaldırılmasında ve bu bireylerin etkinlikle ilgilenme davranışları üzerinde etkili bir yöntem olarak görüldüğü ortaya konulmuştur. Araştırmada, işlevsel iletişim öğretimi örneklemin hem ebeveynleri hem de öğretmeni tarafından örneklemin problem davranışları üzerinde oldukça etkili görülmüştür. Erbaş (2001) gelişimsel geriliği olan bireylerin problem davranışlarının ortadan kaldırılmasında işlevsel iletişim öğretimi uygulamasının sönmeyle birlikte ve sönme olmaksızın etkililiklerinin karşılaştırılmasını araştırmıştır. Sonuçta işlevsel iletişim öğretimi ile sönme uygulamasının problem davranışları ortadan kaldırdığını ve iletişim davranışlarının kullanılmasında güçlü bir yöntem olduğunu ifade etmiştir. Erbaş (2001) araştırmada örneklemlerin ebeveynleri ve öğretmenleriyle işlevsel iletişim öğretimin sosyal geçerliliğine yönelik sonuçlar ortaya koymuştur. Bu sonuçlara göre: bütün örneklemler işlevsel iletişim öğretimi ve sönme uygulamasının etkili bir yöntem olduğunu ifade ettikleri görülmektedir.

\section{Öneriler}

1. Araştırma, birbirinden bağımsız ancak işlevsel olarak benzer üç ayrı ortamda gerçekleştiği için, iç geçerliliği etkileyen etmenlerden olgunlaşma ile sınanma etmenlerinin görülmesinin gizlenmiş olabileceği düşünülebilir. Bundan hareketle ileriki araştırmaların tek bir ortamda yürütülmesi önerilmektedir 
YYÜ Eğitim Fakültesi Dergisi (YYU Journal of Education Faculty), 2021;18(2)152-182,http://efdergi.yyu.edu.tr,

ISSN: 1305-2020

2. $\mathrm{Bu}$ araştırmada işlevsel iletişim öğretimi tek örneklem ile yürütülmüştür. Sonraki benzer araştırmaların birden fazla örneklem ile yapılması önerilmektedir.

3. Bu araştırmada işlevsel iletişim öğretimin problem davranışlar ve etkinlikle ilgilenme davranışları üzerindeki etkileri araştırılmıştır. Benzer araştırmaların yeni veya var olan iletişim davranışlarının kullanılmasının arttırılmasına yönelik yapılması önerilmektedir.

\section{Makalenin Bilimdeki Konumu}

Otizm Spektrum Bozukluğu, Özel Eğitim Bölümü

\section{Makalenin Bilimdeki Özgünlüğü}

Alanyazında OSB olan bireylerin problem davranışlarını ortadan kaldırmak ve iletişim becerileri kazandırmak amacıyla seçilecek stratejilerin sistemli ve bilimsel dayanaklı olmasının önemi ortaya konulmuştur. Ulusal Otizm Merkezi (National Autism Center, NAC) ve Amerika Ulusal Mesleki Gelişim Merkezi (National Professional Development Center on Autism Spectrum Disorder, NPDC) OSB olan bireyler için uygulanacak etkili uygulamaları çeşitli araştırmalarla belirlemişlerdir. İşlevsel iletişim öğretimi (functional communication training), etkileşim ve iletişim yetersizliği nedeniyle problem davranışlar sergileyen OSB'li bireylerin eğitiminde kullanılması etkili görülen bir bilimsel dayanaklı uygulama olarak rapor edilmiştir. Problem davranışların ortadan kaldırılmasında işlevsel iletişim öğretiminin etkili olduğunu ortaya koyan araştırma bulguları olmasına rağmen alanyazında OSB'li bireylerin problem davranışlarının ortadan kaldırılması ve etkinlikle ilgilenme davranışlarının arttırılmasına yönelik yeterli sayıda araştırmanın olmadığı görülmüştür. $\mathrm{Bu}$ araştırma böyle bir ihtiyaçtan doğmuştur. $\mathrm{Bu}$ araştırmada, OSB'li bireylerin problem davranışlarının ortadan kaldırılmasında ve etkinlikle ilgilenme davranışlarının arttırılmasında işlevsel iletişim öğretimin etkililiğini ve verimliliğini belirleme açısından önemli bir çalışma olmuştur.

\section{Kaynakça}

American Psychiatric Association. (2013). Diagnostic and statistical manual of mental disorders: DSM-V. American Psychiatric Pub.

Aydın, A. (2008). Otizmde ilk adım. İstanbul: Epsilon yayıncılık. 
Boyle, M. A., Ortman, M. E., Beckman, A. C., Aholt, S. L., \& Keenan, G. L. (2018). Functional communication training and noncontingent reinforcement in treatment of stereotypy. Behavioral Interventions, 33(1), 79-86.

Braithwaite, K. L., \& Richdale, A. L. (2000) Functional communication training to replace challenging behaviors across two behavioral outcomes. Behavioral Intervention, 15, 21-36.

Carr, E. G. ve Carlson, R. M. (1993). "Reduction of severe behavior problems in the community using a multicomponent treatment approach." Journal of Applied Behavior Analysis, 26, 157-172.

Carr, E. G. \& Durand , M. V. (1985). Reducing behavior problems through functional communication training. Journal Of Applied Behavior Analysis. 189 111-126.

Carr, E. G., Levin, L., McConnachie, G., Carlson, J. I., Kemp, D. C., ve Smith, C. S. Communication-Based Intervention for Problem Behavior: A User's Guide for Producing Positive Change. Baltimore: Paul H. Brookes, 994.

Cowan, R. J., \& Allen, K. D. (2007). Using naturalistic procedures to enhance learning in individuals with autism: A focus on generalized teaching within the school setting. Psychology in the Schools, 44, 701-715.

Creswell, J. W. (2017). Araştırma deseni. Nitel, nicel ve karma yöntem yaklaşımları. S. Beşir Demir. (Çev. Ed.). Ankara. Eğiten Kitap.

Çopuroğlu, Y. C. \& Mengi A. (2014). Toplumsal Dışlanma ve Otizm. [Social exclusion and autism]. Turkish Studies, 9(5), 607-626.

Darıca, N., Abidoğlu, Ü. ve Gümüşçü, Ş. (2002). Otizm ve otistik çocuklar. İstanbul: Özgür Yayınları.

Demir, Ş. (2017).Öncüllere Dayalı Uygulamalar. D. Erbaş, Ş. Yücesoy-Özkan (Ed.), Uygulamalı Davranış Analizi (401-438). Ankara: Pegem Akademi Yayınları

Diken, İ.H. ve Bakkaloğlu, H. (Eds). (2016). Zihinsel Yetersizliği Ve Otizm Spektrum Bozukluğu. Ankara. Pegem Akademi Yayıncılık.

Durand, V. M. (1999). Functional communication training using assistive devices: Recruiting natural communities of reinforcement. Journal of Applied Behavior Analysis, 32, 247-267. 
Duran, V. M. ( 1999). Functional communication training using assitive devices: recruiting natural communities of reinforcement. Journal of Applied Behavior Analysis, 32, 247-267.

Erbaş, D. (2001) Gelişimsel geriliği olan çocukların problem davranışlarının azaltılmasında işlevsel iletişim ögretiminin sönmeyle birlikte ve sönme olmaksızın uygulanmasının etkililiklerinin karşılaştırılması. Yayınlamış doktora tezi, Anadolu Üniversitesi Sosyal Bilimler Enstitüsü, Eskişehir.

Erbaş, D. (2017). Problem Davranışların İşlevlerini Belirleme. D. Erbaş, Ş. YücesoyÖzkan (Ed.), Uygulamalı Davranış Analizi (401-438). Ankara: Pegem Akademi Yayınları

Fisher, W. W., Adelinis, J. D., Thompson, R. H., Worsdell, A. S. \& Zarcone, J. R. (1998). "Functional analysis and treatment of destructive behavior maintained by termination of “don't” (and symmetrical “do”) requests.” Journal of Applied Behavior Analysis, 31, 339-356.

Fisher, W. W., Adelinis, J. D., Volkert, V. M., Keeney, K. M., Neidert, P. L.,\& Hovanetz, A. (2004). Assessing preferences for positive and negative reinforcement during treatment ofdestructive behavior with functional communication training. Research in Developmental Disabilities, 26, 153-168.

Gerow, S., Radhakrishnan, S., Davis, T. N., Hodges, A., \& Feind, A. (2020). A Comparison of Demand Fading and a Dense Schedule of Reinforcement During Functional Communication Training. Behavior analysis in practice, 13(1), 90-103.

Ghaemmaghami, M., Hanley, G. P., \& Jessel, J. (2021). Functional communication training: From efficacy to effectiveness. Journal of Applied Behavior Analysis, 54(1), 122-143.

Hagopian, L. P., Contrucci Kuhn, S. A., Long, E. S., \& Rush, K. S. (2005). Schedule thinning following communication training: Using competing stimuli to enhance tolerance to decrements in reinforcer density. Journal of Applied Behavior Analysis, 38(2), 177-193.

Ingersoll, B., \& Dvortcsak, A. (2006). Including parent training in the early childhood special education curriculum for children with autism spectrum disorders. Topics in Early Childhood Special Education, 26, 179-187.

Ingersoll, B. ve Dvortcsak, A. (2010). Teaching social communication to children with autism. New York: The Guilford Press. 
Kırcaali-İftar, G. (2007). Otizm Spektrum Bozukluğu. İstanbul: Daktylos Yayınları. Kırcaali-İftar, G. (2012). Otizm Spektrum Bozukluğuna Genel Bakış. Tekin-İftar, E. (Ed.), Otizm spektrum bozukluğu olan çocuklar ve eğitimleri (17-26). Ankara: Vize Yayıncilik

Kunt. S. (2010). Otizm el rehberi. İstanbul: Sistem yayıncılık.

Kurt, O. (2012). Davranış Artırma ve Azaltma Yöntemleri. E. Tekin-İftar (Ed.), Eğitim ve Davranış Bilimlerinde Tek-Denekli Araştırmalar (41-68). Ankara: Türk Psikologlar Derneği Yayınları

Mengi, A. (2019). Sosyolojik Boyutlarlyla Otizm. Ankara: Anı Yayıncılık.

Mengi, A. ve Alpdoğan, Y. (2020). Covıd-19 salgını sürecinde özel eğitim öğrencilerinin uzaktan eğitim süreçlerine ilişkin öğretmen görüşlerinin incelenmesi. Milli Eğitim Dergisi. DOI: 10.37669/milliegitim.776226.

National Research Council (2001). Education of children with autism. Committee on Educational Interventions for Children With Autism, C. Lord \& J.P. McGee (Edt), Division of Behavioral and Social Sciences and Education. Washington, DC: National Academy Press.

NPDC (The National Professional Development Center on Autism Spectrum Disorders) (2014).

O’Brien, M. J., Pelzel, K. E., Hendrix, N. M., Schieltz, K. M., Miller, K., Call, N. A., ... \& Lindgren, S. D. (2021). Parent Ratings of Generalized and Indirect Effects of Functional Communication Training for Children with Autism Spectrum Disorder. Behavior Modification, 01454455211018815.

Richman, D. M., Wacker, D. P., \& Winborn, L. (2001). Response efficiency during functional communication training: effects of effort on responce allocation. Journal of Applied Behavior Analysis, 34, 73-76.

Suess, A. N., Schieltz, K. M., Wacker, D. P., Detrick, J., \& Podlesnik, C. A. (2020). An evaluation of resurgence following functional communication training conducted in alternative antecedent contexts via telehealth. Journal of the experimental analysis of behavior, 113(1), 278-301.

Sucuoğlu, B. (2009). Otizm ve otistik bozukluğu olan çocuklar. A. Ataman, (Ed), Özel Ĕ̌itime giriş içinde (291-312). Ankara: Gündüz Eğitim ve Yayıncılık. 
Sucuoğlu, B. (2012). Otizm Spektrum Bozukluğu Olan Çocukların Problem

Davranışlarının Azaltılması. Tekin-İftar, E. (Ed.), Otizm spektrum bozukluğu olan çocuklar ve eğitimleri (183--236). Ankara: Vize Yayıncılık

Sönmez, M. ve Diken İ. H.(2010). Problem davranışların azaltılmasında işlevsel iletişim öğretiminin etkililiği: betimsel ve meta-analiz çalışması. Ankara Üniversitesi Ĕ̆itim Bilimleri Fakültesi Özel Eğitim Dergisi:11(1) 1-16

Sönmez, M. ve Vuran, S. (2008). Sosyal Geçerlik Kavramı ve Türkiye'de Özel Eğitim Alanında Yürütülen Lisansüstü Tezlerde Sosyal Geçerliğin Değerlendirilmesi. Ankara Üniversitesi Eğitim Bilimleri Fakültesi Özel Eğitim Dergisi. No:9(1)55-65 Winborn, L., Wacker, D. P., Richman, D. M., Asmus, J., \& Geier, D. (2002). Assessment of mand selection for functional communation training packages. Journal of Applied Behavior Analysis, 35, 295-298.

Worsdell, A. S., Iwata, B. A., Hanley, G. P., Thompson, R. H., \& Woo Kang, S. (2000). Effects of continuous and intermittent reinforcement for problem behavior during functional communication training. Journal of Applied Behavior Analysis 33(2), 167-179.

Vural, İ. (2007), SOS Otizm ve İletisim Yetersizliği Olan Çocukların Eğitimi. İstanbul: Evrim Yayınevi.

Yücesoy-Özkan, Ş. (2017). Hedef Davranışları Kaydetme ve Güvenirlik. D. Erbaş, Ş. Yücesoy-Özkan (Ed.), Uygulamalı Davranış Analizi (401-438). Ankara: Pegem Akademi Yayınları

Yücesoy Özkan, Ş., Ergenekon, Y., Çolak, A., Kaya, Ö. (2014). Otizm Spektrum Bozukluğu Aile Bilgilendirme Rehberi. Ankara: Aile ve Sosyal Politikalar Bakanlığ

\section{Summary}

\section{Purpose and Significance}

The concept of ASD, education and development of individuals with ASD are among the most discussed topics today (Mengi, 2019). In individuals with ASD, problem behavior originated from inadequacies seen in their social interaction and communication (Winborn et al., 2002). In the literature, it has been shown that problem behaviors in individuals with ASD mostly serve the purposes of obtaining attention, object acquisition, sensory stimulus, and escape / avoidance (Erbaş, 2005). Various strategies can be used to eliminate the problem behaviors of individuals with ASD and besides, these strategies can 
be used to help them gain communication skills (Detrich, 2012; NAC, 2010; Tekin-İftar \& Olçay-Gül, 2012). The most important point to be considered in the selection and use of strategies is that the strategies should be systematic and scientifically based (Cowan \& Allen, 2007). In the NCAEP 2020 report published by the American National Center for Professional Development, 28 practices for individuals with ASD were seen as scientifically based. According to the report, functional communication training is a scientific-based practice that is considered effective in the education of individuals with ASD who exhibit problem behaviors due to lack of interaction and communication. By focusing on the premises, functional communication teaching eliminates problem behaviors, and also supports and increases communication behaviors (Carr \& Durand, 1985; Ingersoll \& Dvortcsak, 2006). Although there are research findings that reveal that functional communication teaching is effective in eliminating problem behaviors, it has been observed that there are not enough studies in the literature that aim at eliminating problem behaviors of individuals with ASD and increasing their interest behaviors in activity. This research aims to determine the effectiveness and efficiency of the applications in which functional communication teaching is used in eliminating the problem behaviors of individuals with ASD and increasing their interest behavior towards the activity, considering the above-mentioned benefits.

\section{Method}

In this study, among the single-subjet study models, multiple-probe-model with probe phase model with probe was used. And the independent variable is the problem behavior which are exhibited by the participant and the interest behaviors in the activity. The research was carried out in the city center of Bolu, in the living room of the house where the participant lived, in the classroom of the school where the participant was studying and in the gymnasium of their school. There were 2 participants in the research. A pilot study was conducted with one of the participants yet the actual was caried out with the other. According to the data which was obtained in the pilot study, no problem was seen in the research program and so it was concluded to make no change in the program. Three types of data were collected and analyzed in the study: effectiveness, social validity and reliability data. 


\section{Findings}

The findings of this study consist; functional evaluation findings, effectiveness, monitoring and social validity findings.

In this part of the research, during the functional evaluation process; interviews with the participant's teacher and mother, and the evaluation of the data obtained from one-to-one observations took place. At the end of the interviews, it was observed that the participant displayed problem behaviors in the form of throwing objects when he wanted to obtain an object, and hitting and biting when he realized that he was given a difficult task or that he would face responsibility. In the research, the data obtained from direct observations and the data obtained as a result of interviews were found to be parallel. Therefore, a hypothesis has been developed that argues the functions of problem behaviors are to obtain objects and to escape from a difficult task.

When we look at the effectiveness of functional communication teaching, it is seen that the problem behavior rate of the participant decreases and the behaviors of engaging with the activity increase in the sessions where functional communication teaching is performed. Therefore, this study revealed that functional communication teaching is effective in eliminating the problem behaviors of an individual with ASD and increasing their interest behaviors with an activity.

Follow-up sessions were held in order to reveal whether the behaviors were maintained even after the teaching sessions were completed. One monitoring trial was included for each three application stages. When data in the follow-up sessions were examined, it was seen that the participant continued permorming the behaviors wich he acquired even after teaching sessions ended.

According to the social validity findings obtained as a result of interviews with the parents and teachers of the participant, functional communication teaching is seen as an effective method in eliminating problem behaviors and increasing activity-related behaviors.

\section{Discussion and conclusion}

At the end of the research; these three arguments are obtained: a) Functional communication teaching is effective on the problem behaviors and activity-related behaviors of an individual with ASD, b) The behaviors acquired in teaching are continued 
after the education is completed, c) According to the social validity findings supported by the participant's parents and special education experts, the functional communication teaching method is effective in a positive way.

Carr and Carlson (1993) suggested using experimental-descriptive techniques together to determine problem behaviors and their functions. So in this study, as well, data obtained from direct observations, teacher and parent interviews were used for functional assessment. In the study, the use of skills that function similar to the participant's problem behaviors and the participant's interest in these skills (Durand, 1999) reveal the contribution of functional assessment to functional communication teaching programs.

The data presented in the results of this study and the results found in Durand's (1999) research shows parallelism. Durand (1999), in his study, determined the problem behaviors of five participants and the functions of these behaviors. He revealed these functions as escaping from a difficult task, obtaining objects, and attracting attention. As a result of the functional evaluation, the participants were taught alternative communication skills instead of the variables that sustain the problem behaviors. As a result of the research, an increase in the behaviors of engaging with activity was observed in the participants whose truancy behaviors disappeared. In addition, the results of this study are similar to the results of Braithwaite and Richdale, (2000), Erbaş (2001), Fisher et al. (1998), Hagopian et al. (2005), Worsdell, et al. (2000).

According to the results of the research, it can be said that by increasing the use of this method, it can be supported to eliminate problem behaviors of individuals, increase their interest in activity and communication behavior. It is believed that this study will contribute to the literature, since there are few studies in the literature where functional communication teaching is applied to eliminate problem behaviors.

At the end of the research, to carry out future studies with participants who do not have language and speaking skills, to conduct similar studies in an environment with more than one participant, to conduct research to increase the use of new or existing communication behaviors, and to investigate the effectiveness of teaching by using voice recorder as an alternative communication in studies is recommended. 